\title{
UNIVERSITYOF
}

FORWARD

THINKING

WESTMINSTER用

WestminsterResearch

http://www.westminster.ac.uk/westminsterresearch

Media Research and Psychoanalysis: A Suggestion

Johanssen, J.

This is an accepted manuscript version of an article published by Sage in the International Communication Gazette on 1st July 2016. It is available online at:

http://dx.doi.org/10.1177/1748048516655730

(C) The author (s).

The WestminsterResearch online digital archive at the University of Westminster aims to make the research output of the University available to a wider audience. Copyright and Moral Rights remain with the authors and/or copyright owners.

Whilst further distribution of specific materials from within this archive is forbidden, you may freely distribute the URL of WestminsterResearch: ((http://westminsterresearch.wmin.ac.uk/)).

In case of abuse or copyright appearing without permission e-mail repository@westminster.ac.uk 


\section{Media Research and Psychoanalysis: A Suggestion}

\section{Jacob Johanssen}

\section{$<$ J.Johanssen@westminster.ac.uk>}

This short commentary outlines psychoanalysis as a theory and method and its potential value to media research. Following Dahlgren (2013), it is suggested that psychoanalysis may enrich the field because it may offer a complex theory of the human subject, as well as methodological means of doing justice to the richness, ambivalence and contradictions of human experience. The psychoanalytic technique of free association and how it has been adapted in social research (Hollway and Jefferson 2000) is suggested as a means to open up subjective modes of expression and thinking - in researchers and research participants alike that lie beyond rationality and conscious agency.

\section{Introduction}

Rather than attempting a lengthy discussion of the implicit and explicit history of cognitivism and its hue of rationality within media and communication research, this contribution suggests a way to enrich the field by drawing on psychoanalytic theories and methods.

Peter Dahlgren's (2013) recent suggestion on 'reactivating concerns about the subject' (2013: 73) in media studies research marks my starting point. He argues that media and communication studies consist of 'implicit models and assumptions about how people [...] actually function' (Dahlgren, 2013: 72). While much of media research revolves around the human subject as a media user, consumer or producer who that subject actually is or how she should be conceptualised in relation to the media is seldom addressed or debated. Dahlgren expresses thus dissatisfaction with the state of media research in general when it comes to theoretical conceptualisations and empirical research of the human subject as a media user and he specifically suggests (Freudian and post-Freudian) psychoanalysis as a way forward. A key question he asks in this context is:

What if the subject cannot fully understand why he or she does and says all the things that he or she does? Do we really understand just why we respond to, say, political humor, in the ways that we do? (Dahlgren, 2013: 81) 
Dahlgren touches a nerve within wider social research traditions here. As scholars, we often assume that people act as rational agents and approach them as people who are able to "tell it like it is' in a research encounter for example. Wendy Hollway and Tony Jefferson note that in social research generally there are

widespread assumptions in the tradition [of social research], by ethnographers, participant observers and interviewers alike, that their participants are 'telling it like it is', that participants know who they are and what makes them tick - what we might call the 'transparent self problem' - and are willing and able to 'tell' this to a stranger interviewer - what we might call the 'transparent account problem'. (Hollway and Jefferson, 2000: 3)

How shall we respond to such claims? I would like to argue that psychoanalysis may offer us the tools and vocabulary to acknowledge subjectivity and modes of experience beyond rationality - and these always include foci on ourselves as media researchers and how we are invested in a particular topic. By thinking about and approaching the human subject as a dynamic and processual being, we may be able to do more justice to the complexities of human experience in relation to media.

\section{Psychoanalysis as a Theory of the Subject}

Sigmund Freud's oeuvre is peppered with references to and examples of media and their content in the broadest sense. He used plays, literature, poetry and ancient archaeological examples to illustrate his clinical and theoretical ideas (Bainbridge and Yates, 2014). From the very beginning psychoanalysis and (popular) culture were intertwined. Cinema and psychoanalysis came into being at roughly the same time (Elsaesser, 2009). One could thus argue that two distinct 'technologies' share the same historical and social circumstances.

Psychoanalysis is, first of all, a clinical method that is underscored by a body of theoretical work from different thinkers-Freud, Winnicott, Klein, Lacan, come immediately to mind. To define it, psychoanalysis, then, is the study of personality and behaviour determined by conflicts connected with experiences as a child. It is a method of investigation which consists essentially in bringing out the meaning of the words, the actions and the products of the imagination and the unknown. Psychoanalysis seeks to theorise a subject who is not always aware of aspects of her self. Psychoanalysts think about the subject in a certain way. For them, the subject is a subject of conflicts, dynamics, multiple layers, contradictions and 
complexity (Freud, 1978). While psychoanalysis is a clinical field, its epistemological and ontological foundations have trickled down to the humanities (film theory in particular) and the social sciences. Some media researchers drew on and continue to work with psychoanalysis to varying degrees (Radway 1984; Walkerdine 1984; Ang 1985; Turkle 1995; Hills 2002; Richards 2007; Kavka 2009; Balick 2013; Dahlgren 2013; Yates and Bainbridge 2014; Carpentier 2014a, b; Krüger and Johanssen 2014, Johanssen 2016).

Dahlgren (2013) advocates that psychoanalytic theories can help scholars to think about the complex questions of using and making sense of media and mediums. Subjects may not always fully know why or how they have come to like a specific television programme for example. To Dahlgren, media researchers need to consider 'all the other communicative modes beyond the rational' (Dahlgren, 2013: 82) because media content is not just about cognitive and rational categories like 'information and formal argument' (ibid). Its process of consumption and understanding is equally about consciousness, as well as affect and the unconscious. As a discipline, psychoanalysis, then, shifts the attention from rationality to contradictions, incoherences, ambivalent and non-sensical subjective experiences that also find expression in cultural products such as media texts and in responses towards them. Ben Highmore (2006; 2007) defined psychoanalysis as a particular mode of 'attention' (Highmore, 2007: 88) that always includes a focus beyond the rational. Psychoanalysis views the subject as processual, emergent and dynamic. As my commentary is limited here, I shall illustrate these abstract discussions so far by spelling out what implications psychoanalysis may have for questions of methodology in interview based research.

\section{Psychoanalysis as Methodology}

If, as Freud maintained, psychoanalysis is a method (Devereux, 1967; Freud 1978), how might it be of value for media and communication studies? Psychoanalytically informed research upholds the notion that 'unconscious processes infiltrate the narrative accounts given by research participants, so that interpretive strategies aimed at uncovering these unconscious processes will be needed.' (Frosh, 2010: 200). This is not to say that psychoanalysis offers a language with which to decode or decipher how a participant might really 'tick' or claiming to know something that the participant is not aware of. Rather, it may be beneficial to think of a research participant 'whose inner world is not simply a reflection of the outer world, nor a cognitively driven rational accommodation to it.' (Hollway and Jefferson, 2000: 4). From such a perspective results the need to open up spaces of expression that are not limited by a pure question-answer dynamic as in many qualitative interviews in media use research for 
instance. Such an opening up may, I suggest, be brought about through the psychoanalytic technique of free association. The idea of free association is one of the core principles of psychoanalysis. Sigmund Freud encouraged his patients to freely associate because he believed this would allow unconscious moments to come to the surface. It is precisely by asking the patient to freely associate that 'nothing can occur to him which is not in an indirect fashion dependent on the complex we are in search of.' (Freud, 1978: 32). In that sense, free associations are never completely free. In other words, free association enables a flow of utterances that, according to Freud, were not entirely subject to conscious censorship. Repressed, forgotten, or negated fragments could thus come to the surface. The researcher should remain in an 'evenly-suspended-attention' (Freud, 1981: 111). Freud supplied a vivid image that underpins the idea of evenly suspended attention: the psychoanalyst turns his/her unconscious 'like a receptive organ' (Freud, 1981: 115) towards the patient, they are angled towards each other, just like 'the telephone receiver is adjusted to the transmitting microphone' (ibid.: 116). For Freud, silences often occur not because the patient has finished talking but because they hold back an idea that has come into their mind in a resistant manner. To the patient's mind, that idea or thought could not be important to the psychoanalyst. This kind of self-censorship has to be broken down in the analysis by gently but firmly assuring the patient that, in fact, everything is relevant (Freud, 1978: 31). It is these side effects that psychoanalysis puts centre stage. The irrelevant becomes relevant. This Freudian technique has been adapted by the psychosocial researchers Wendy Hollway and Tony Jefferson (2000). While maintaining a general research question that should inform the research encounter between researcher and participant, the authors suggest that a participant should talk about anything that comes to mind in the interview. In that way the interview is not structured according to a formalist, conscious logic but according to an unconscious one: 'the associations follow pathways defined by emotional motivations, rather than rational intentions' (ibid.: 37). In addressing the subject in a more complex way, one may open up ways of responding in a less restricted and conscious way than in traditional interviews. In this way, one may be able to 'secure access to a person's concerns which would probably not be visible using a more traditional method' (ibid.: 37). The emphasis here is less on coherence and consciousness than in traditional social research. As a result, data that is richer, more complex and ambivalent may be generated and interpreted by drawing on psychoanalytic ideas.

The ideas I have put forward in this commentary shall act as a suggestion to think and approach the human in more complex ways in media research. We may never fully know or 
understand the subject but psychoanalysis may help us to acknowledge a different way of thinking and addressing her in our work.

\section{References}

Ang, I. (1985) Watching dallas. Soap opera and the melodramatic imagination. London: Routledge.

Balick, A. (2013) The psychodynamics of social networking. Connected-up instantaneous culture and the self. London: Karnac Boooks.

Bainbridge, C. and Yates, C. (eds.) (2014) Media and the inner world. Psycho-cultural approaches to emotion, media and popular culture. Basingstoke: Palgrave Macmillan.

Carpentier, N. (2014a) 'Participation as a fantasy. A psychoanalytical approach to powersharing fantasies', in Kramp, L., Carpentier, N., Tomanić Trivundža, I., Nieminen, H., Kunelius, R., Olsson, T., Sundin, E. and Kilborn, R. (eds.). Media practice and everyday agency in europe. Bremen: Edition Lumière, 319-330.

Carpentier, N. (2014b) 'Fuck the clowns from Grease!!' Fantasies of participation and agency in the youtube comments on a cypriot problem documentary', Information, Communication \& Society, 17 (8): 1001-1016.

Dahlgren, P. (2013) 'Tracking the civic subject in the media landscape. Versions of the democratic ideal', Television \& New Media, 14, (1): 71-88.

Devereux, G. (1967) From anxiety to method in the behavioral sciences. The Hague: Mouton $\&$ Co.

Elsaesser, T. (2009) 'Freud as media theorist. Mystic writing-pads and the matter of memory', Screen, 50, (1): 100-113.

Freud, S. (1978) Five lectures on psycho-analysis. The standard edition of the complete psychological works of sigmund freud. Volume XI. Five lectures on psycho-analysis, leonardo da vinci and other works. London: The Hogarth Press and the Institute of Psycho-Analysis.

Freud, S. (1981) Recommendations to physicians practicing psycho-analysis. The standard edition of the complete psychological works of sigmund freud. Volume XII. The case of schreber, papers on technique and other works. London: The Hogarth Press and the Institute of Psycho-Analysis.

Frosh, S. (2010) Psychoanalysis outside the clinic. Interventions in psychosocial studies. Basingstoke: Palgrave Macmillan. 
Hollway, W. and Jefferson, T. (2000) Doing qualitative research differently. Free association, narrative and the Interview method. London: Sage.

Highmore, B. (2006) Michel de certeau. Analysing culture. London: Continuum.

Highmore, B. (2007) 'Michel de certeau and the possibilites of psychoanalytic cultural studies', in Bainbridge, C., Radstone, S., Rustin, M., Yates, C. (eds.). Culture and the unconscious. Basingstoke: Palgrave Macmillan, 88-101.

Hills, M. (2002) Fan cultures. London: Routledge.

Johanssen, J. (2016) 'Did we fail? (Counter-)transference in a qualitative media research interview', Interactions: Studies in Communication \& Culture, 7 (1), forthcoming.

Kavka, M. (2009) Reality television, affect and intimacy. Reality matters. Basingstoke: Palgrave Macmillan.

Krüger, S. and Johanssen, J. (2014) 'Alienation and digital labour. A depth-hermeneutic inquiry into online commodification and the unconscious', Triple $C$, 12, (2): 632-647.

Radway, J. A. (1984). Reading the romance. Women, patriarchy, and popular literature. Chapel Hill: University of North Carolina Press.

Richards, B. (2007) Emotional governance. Politics, media and terror. Basingstoke: Palgrave Macmillan.

Turkle, S. (1995): Life on screen. Identity in the age of the internet. New York: Simon \& Schuster.

Walkerdine, V. (1986) 'Video replay', in Burgin, V., Donald, J. and Kaplan, C. (eds.) Formations of fantasy. London: Verso, 167-199. 